\title{
NEW CINGULATA (MAMMALIA, XENARTHRA) FROM THE UPPER LUMBRERA FORMATION (BARTONIAN, MIDDLE EOCENE), SALTA PROVINCE, ARGENTINA
}

\author{
CLAUDIA HERRERA (1), GRACIELA ESTEBAN (1) \\ Instituto Superior de Correlación Geológica (INSUGEO), Facultad de Ciencias Naturales e Instituto \\ Miguel Lillo, Universidad Nacional de Tucumán. Miguel Lillo 205, 4000, Tucumán, Argentina. \\ claucordoba@hotmail.com,gracielaiesteban@gmail.com
}

\section{DANIEL A. GARCÍA-LÓPEZ (D), VIRGINIA DERACO (D)}

INSUGEO (CONICET-UNT), Facultad de Ciencias Naturales e Instituto Miguel Lillo, Universidad Nacional de Tucumán. Miguel Lillo 205, 4000, Tucumán, Argentina. dgarcialopez@csnat.unt.edu.ar,virginiaderaco@gmail.com

\section{JUDITH BABOT (D)}

Centro de Investigaciones en Ecología Histórica (CONICET-UNT), Fundación

Miguel Lillo. Miguel Lillo 251, 4000, Tucumán, Argentina.

$$
\text { jubabot@gmail.com }
$$

CECILIA DEL PAPA (1)

CICTERRA-F.C.E.F y N., CONICET-Universidad Nacional de Córdoba, X5016GCA Córdoba, Argentina.

delpapacecilia@yahoo.com

\section{SARA BERTELLI (D, NORBERTO GIANNINI (D)}

Unidad Ejecutora Lillo (CONICET- Fundación Miguel Lillo). Miguel Lillo 251, 4000, Tucumán, Argentina. sbertelli@lillo.org.ar,ngiannini@amnh.org

\begin{abstract}
We describe isolated remains of a Paleogene cingulate from El Simbolar locality, Upper Lumbrera Formation (Bartonian), southern Salta Province, northwestern Argentina. The material consists of numerous fixed, movable, and caudal sheath osteoderms. The specimen has large-sized osteoderms, with a lageniform main figure, as in Utaetus buccatus, U. laxus, U. argos, ?U. deustus, Punatherium catamarcensis, and the basal euphractin Archaeutatus. The combination of morphological characters, in addition to its large size, allows us to recognize a new species of "Utaetini" for the Paleogene of northwestern Argentina. This new species of ?Utaetus represents the oldest record of Euphractinae in this region, and strengthens the endemic condition of its Paleogene faunas.
\end{abstract}

Keywords: Cingulata, osteoderms, El Simbolar, Paleogene, Salta, Argentina.

RESUMO - Nós descrevemos restos isolados de cingulado do Paleógeno da localidade de El Simbolar, Formação Lumbrera Superior (Bartoniano), sul da Província de Salta, noroeste da Argentina. O material consiste em numerosos osteodermos das bandas fixas, móveis e caudais. Os osteodermos têm tamanho grande, com uma figura principal de aspecto lageniforme, como em Utaetus buccatus, U. laxus, U. argos, ?U. deustus, Punatherium catamarcensis, e o eufractino basal Archaeutatus. A combinação de caracteres morfológicos, em adição ao seu grande tamanho, nos permite reconhecer uma nova espécie de "Utaetini” para o Paleógeno do noroeste da Argentina. Esta nova espécie de ?Utaetus representa o registro mais antigo para Euphractinae nesta região e fortalece a condição endêmica das faunas paleógenas no noroeste da Argentina.

Palavras-chave: Cingulata, osteodermos, El Simbolar, Paleógeno, Salta, Argentina. 


\section{INTRODUCTION}

Cingulata are a diverse and relatively abundant group of eutherian mammals characteristic of the South American Cenozoic. The evolutionary history of cingulates in particular, and xenarthrans in general, is deeply linked to the protracted isolation of South America (SA) and the concomitant evolution of endemic faunas in the continent. During the late Pliocene ( $3.5 \mathrm{Ma})$, at the beginning of the Great American Biotic Interchange (GABI), cingulates spread into Central and North America (Patterson \& Pascual, 1968; Cione et al., 2015), currently occupying different biomes between approximately $40^{\circ} \mathrm{N}$ and $40^{\circ} \mathrm{S}$ in the Americas (Castro, 2015; Soibelzon et al., 2015).

The external morphology of osteoderms has played an important role in traditional systematic assessments of the group (Carlini et al., 2009; Ciancio, 2016 and references therein), given that the isolated osteoderms are the most frequently preserved elements of the Cingulata skeleton in the fossil record (Carlini et al., 2010). The earliest record of cingulates is represented by isolated osteoderms of Riostegotherium (Astegotheriini), from the early Eocene locality of São José de Itaboraí in Southeast Brazil (Oliveira \& Bergqvist, 1998; Bergqvist et al., 2004; Gelfo et al., 2009; Woodburne et al., 2014). The rich Cenozoic fossil record of cingulates from Argentina comprises the bulk of the current knowledge on the systematics of the group. In Patagonia, the oldest cingulate comes from the early Eocene (Simpson, 1948). In the Paso del Sapo Fauna, all the cingulate remains have been assigned to different Astegotheriini species, representing the most diverse record of the group (Tejedor et al., 2009; Carlini et al., 2010; Ciancio et al., 2013). By the middle Eocene, cingulates become more diverse and the first undoubtly Euphractinae, Utaetus Ameghino, 1902 is recorded (Simpson, 1948; Carlini et al., 2010). Significantly, there is a subsequent reversal in the relative abundance of the major groups, with Euphractinae becoming dominant over Dasypodinae by the late Eocene (Ciancio, 2016).

In northwestern Argentina (NWA), several Paleogene geological units have produced a rich record of continental mammals (Río Loro, Mealla, Maíz Gordo, Lower Lumbrera, Upper Lumbrera, Casa Grande, Quebrada de los Colorados, and Geste formations), spanning from the Paleocene to the late Eocene (del Papa et al., 2017). Despite the abundant record of mammals (mainly South American native ungulates) in these units, the record of armadillos is sparse and limited to levels from the early to the late Eocene (Lower Lumbrera, Upper Lumbrera, Casa Grande, Quebrada de los Colorados, and Geste formations; Table 1) (Babot et al., 2012, 2017; Ciancio et al., 2016; Herrera \& Powell, 2009; Herrera et al., 2010, 2012, 2016, 2019; Fernicola et al., 2021).

Table 1. Comparative chart of cingulate present in the different Eocene localities of Northwestern Argentina (Herrera \& Powell, 2009; Herrera et al., 2010, 2012, 2016, 2019; Babot et al., 2012, 2017; Ciancio et al., 2016; Fernicola et al., 2021). Abbreviations: (localities grouped by provinces): CTT, Cerro Tin Tin; ES, El Simbolar; JR, Juramento river; LC, Los Cardones; LP, Laguna de Los Pozuelos; LV, Luracatao valley; PG, Pampa Grande (Salta Province); AS, Antofagasta de la Sierra (Catamarca Province); MA: Mina Aguilar (Jujuy Province).

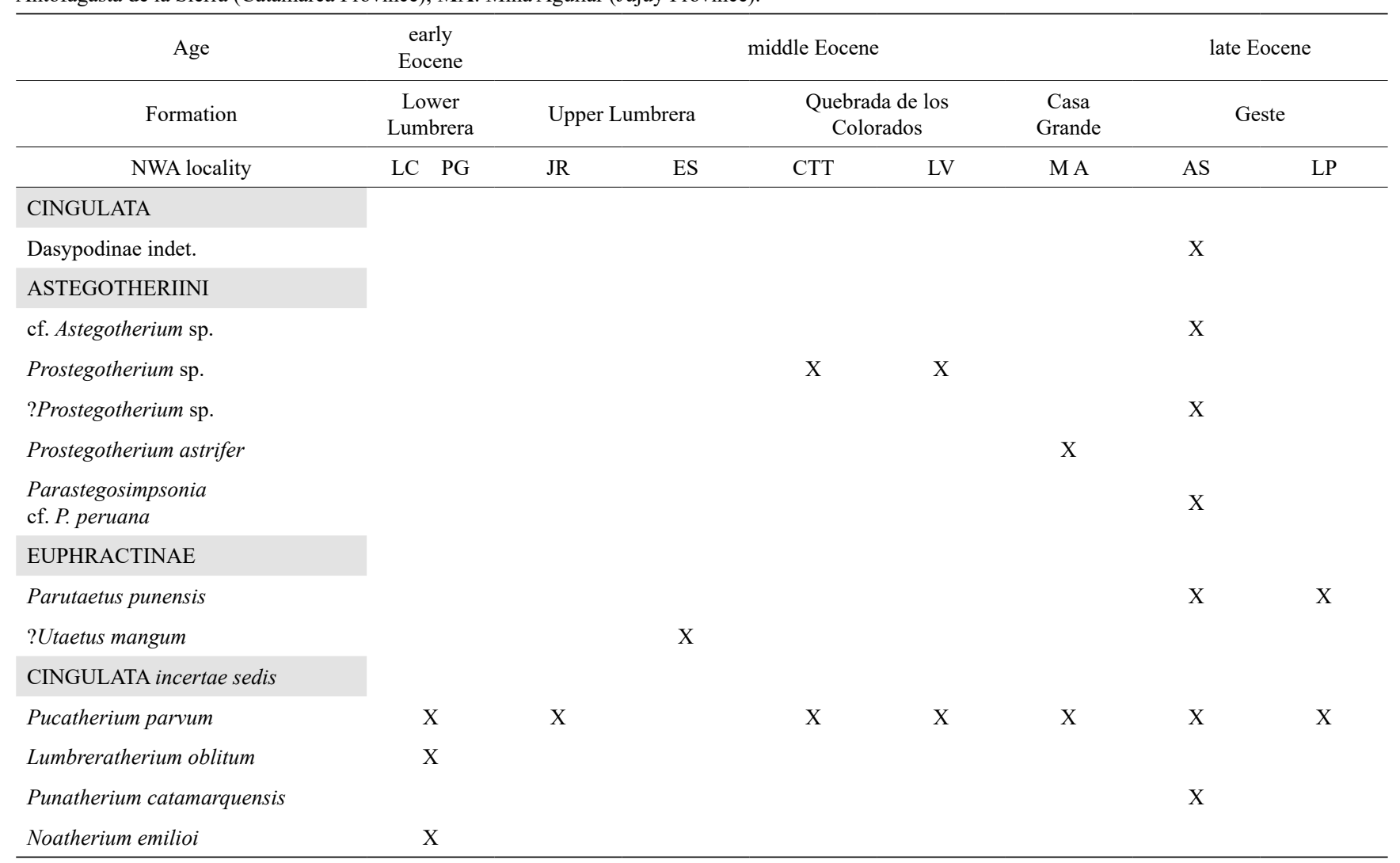


Here we describe numerous fixed, movable, and caudal sheath osteoderms, all from the same individual, of a new large-sized Cingulata recovered at El Simbolar locality, Upper Lumbrera Formation, in southern Salta Province, NWA. We discuss the significance of these new findings within the evolutionary history of the group in the context of early Cenozoic faunal evolution in SA intermediate-latitudes.

\section{MATERIAL AND METHODS}

The specimen of ?Utaetus magnum sp. nov. (IBIGEO-P 109) here described includes several isolated fixed, movable, and caudal sheath osteoderms, all from the same individual, which are deposited in the Colección de Paleontología, Instituto de Bio y Geociencias del Noroeste Argentino, Rosario de Lerma (Salta, Argentina).

Specimens used for comparison include Utaetus buccatus (MACN A-11622A, MPEF PV 5426), Utaetus laxus (MACN 10424, 11295), Utaetus argos (MACN 10445), ?Utaetus deustus (MACN 10431), Pucatherium parvum (PVL 6384, MHAS 068-072), Lumbreratherium oblitum (PVL 4262), Riostegotherium yanei (MCN-PV 1774), Astegotherium dichotomus (MACN A-10421), Stegosimpsonia chubutana (MACN A-10438), Pseudostegotherium glangeaudi (MACN A-12679), Parastegosimpsonia peruana (LACM 150608), Punatherium catamarcensis (MLP 93-VI-1-18, MLP 86V-6-24), Parutaetus punaensis (MLP 83-XI-3-2, MHAS 017-020, 029, PVL 6416, 6575, 6403, 6413-6415, 6407, 6417, 6568), Orthutaetus (MPEF PV 7633B), Anteutatus (MACN A-11621), Yuruatherium tropicalis (LACM 150606), and Archaeutatus malaspinensis (MACN A-10440).

Institutional Abbreviations: IBIGEO-P, Colección de Paleontología Instituto de Bio y Geociencias del Noroeste Argentino, Rosario de Lerma, Salta, Argentina; LACM, Natural History Museum of Los Angeles County, Los Angeles, U.S.A.; MACN, Museo Argentino de Ciencias Naturales "Bernardino Rivadavia", Buenos Aires, Argentina;
MCN-PV, Museu de Ciências Naturais, Secretaria do Meio Ambiente e Infraestrutura do Rio Grande do Sul, Porto Alegre, Brazil; MHAS, Museo del Hombre de Antofagasta de la Sierra, Antofagasta de la Sierra, Catamarca, Argentina; MLP, Museo de La Plata, Facultad de Ciencias Naturales y Museo de La Plata, Universidad Nacional de La Plata, Buenos Aires, Argentina; MPEF PV, Museo Paleontológico Egidio Feruglio, Paleontología Vertebrados, Trelew, Chubut, Argentina; PVL, Colección Paleontología Vertebrados Lillo, Facultad de Ciencias Naturales e Instituto Miguel Lillo, UNT, Tucumán, Argentina.

\section{GEOLOGICAL SETTINGS}

The outcrops of the Upper Lumbrera Formation at El Simbolar, Guachipas Department, Salta Province (Figure 1) are composed of a thick succession of reddish siltstones and sandy siltstones, with sporadic and localized intercalations of fine-grained sandstones and nodules of gypsum/anhydrite. The most outstanding features of this geological unit are its homogeneous lithology and the presence of conspicuous paleosol layers (del Papa et al., 2017). The paleoenvironmental reconstruction suggests that the Upper Lumbrera Formation represents sedimentation in a fine-grained plain, with localized fluvial and ephemeral lacustrine deposits (del Papa, 2006). Indeed, based on granulometric and petrographic analysis of the Upper Lumbrera sediments at El Simbolar, Lapiana et al. (2016) suggested a paleoenvironment of open plains constructed by the aggradation of reworked loess. The fossil-bearing sedimentary layer is formed by red sandy siltstones with root traces, carbonate nodules, ped structures and clay cutans typical of paleosols with wet/dry cycles. The age of the Upper Lumbrera Formation has been estimated in $39.9+/-0.4 \mathrm{Ma}$ $(\mathrm{U} / \mathrm{Pb}$ zircon recovered from a tuff layer close to the upper contact, see del Papa et al., 2010). The age of the fossil is therefore considered as middle Eocene (Bartonian).

Table 2. Compared dimensions (in mm) of movable and fixed osteoderms of ?Utaetus magnum sp. nov. (IBIGEO-P 109), with ?U. deustus, U. buccatus, U. argos, and U. laxus (Ameghino, 1902).

\begin{tabular}{|c|c|c|c|c|c|}
\hline & ?Utaeutus magnum & ?U. deustus & U. buccatus & $U . \operatorname{argos}$ & U. laxus \\
\hline \multicolumn{6}{|c|}{ Fixed osteodems } \\
\hline Length & $17.6-23.1$ & 13 & 14 & 11 & 16 \\
\hline Width & $13.1-17.7$ & 15 & $9-13$ & 8 & 11 \\
\hline Thickness & $6.2-7$ & 6 & $4-6$ & 2.5 & 5 \\
\hline \multicolumn{6}{|c|}{ Movable osteoderms } \\
\hline Length & $41.3-45.5$ & $30-40$ & $20-22$ & ----- & 18.6 \\
\hline Width & $11.2-17.5$ & 15 & $7-9$ & ----- & 8.64 \\
\hline Thickness & $4.3-4.7$ & ----- & 3 & ----- & ----- \\
\hline \multicolumn{6}{|c|}{ Subtriangular osteoderms } \\
\hline Length & $18.8-24.6$ & ----- & ----- & ----- & ----- \\
\hline Width & $12.8-15.4$ & ----- & ----- & ----- & ----- \\
\hline Thickness & $4.3-5.5$ & ----- & ----- & ----- & ----- \\
\hline
\end{tabular}




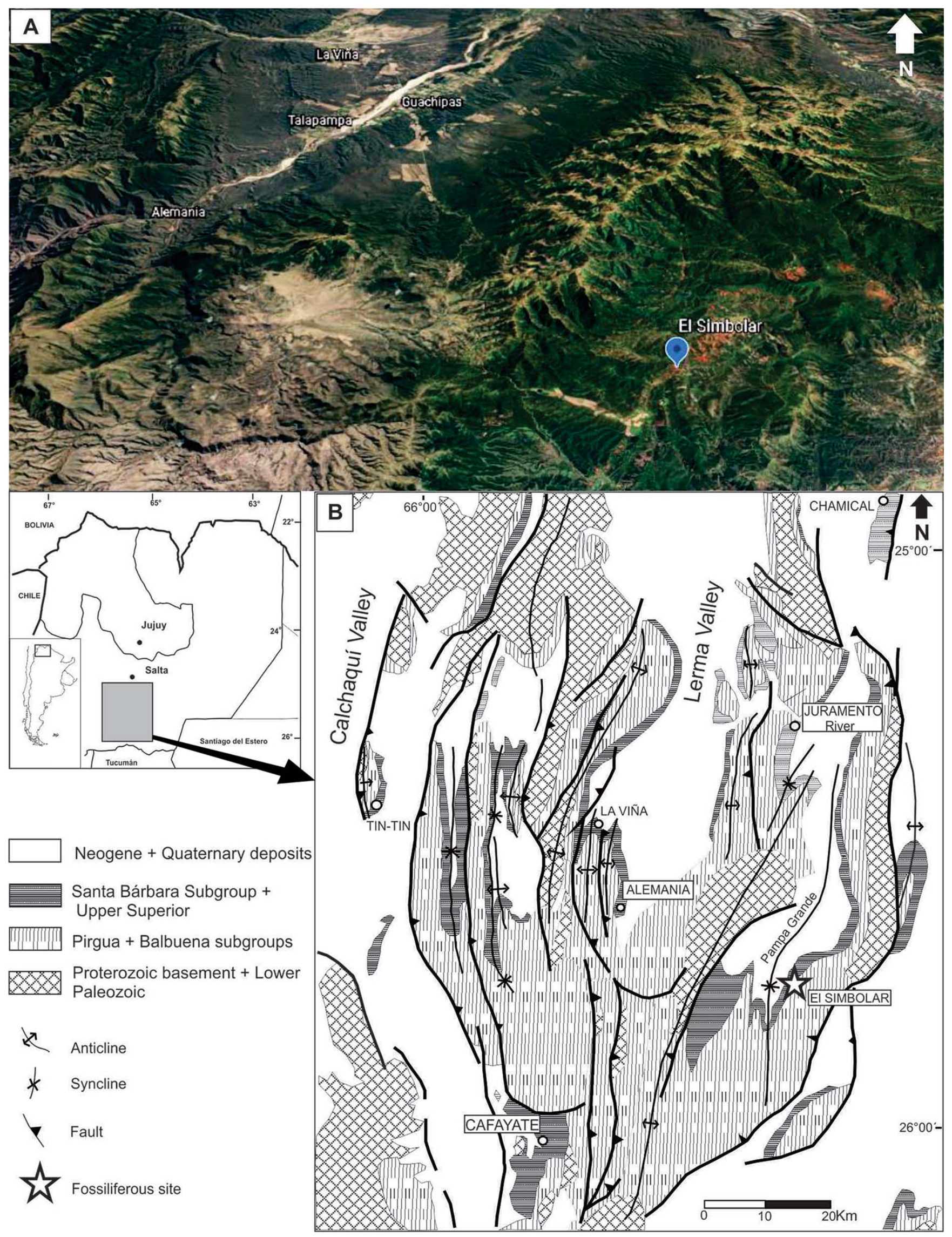

Figure 1. Location of the studied area. A, geographic location of El Simbolar locality, Guachipas Department, Salta Province, Argentina; B, geological map and synthetized stratigraphy showing the location of the fossiliferous site (Upper Lumbrera Formation). 


\section{SYSTEMATIC PALEONTOLOGY}

\author{
XENARTHRA Cope, 1889 \\ CINGULATA Illiger, 1811 \\ CHLAMYPHORIDAE Pocock, 1924 \\ EUPHRACTINAE Winge, 1923 \\ “UTAETINI" Simpson, 1945
}

Utaetus Ameghino, 1902

Type Species. Utaetus buccatus Ameghino, 1902.

?Utaetus magnum sp. nov. urn:1sid:zoobank.org:act:AB845C91-605B-4609-BDB81E90E7A23BBF

(Figure 2)

Etymology. magnum from the Latin magna, large or superior, in reference to the large size of the new taxon in comparison to other closely related forms.

Holotype. IBIGEO-P 109, 11 fixed, two movables, and eight caudal complete osteoderms, in addition to numerous fragmentary osteoderms, all from the same individual.

Geographic and Stratigraphic Provenance. El Simbolar (2543'34.5''S - 65'24'35.4''W), Guachipas Department, Salta Province, Argentina (Figure 1). Upper Lumbrera Formation, middle Eocene (Bartonian). The fossiliferous layer is $23 \mathrm{~m}$ above the base of the unit.

Diagnosis. Large cingulate of inferred size similar to the extant Euphractus sexcintus. Osteoderms larger than ?Utaetus deustus, and one and a half times larger than Utaetus buccatus, U. laxus, and U. argos. Lateral contact area straight, with denticular projections in their entire surface, as in Euphractinae. Fixed and movable osteoderms with a lageniform main figure, as in "Utaetini", in Punatherium catamarcensis, and the basal euphractins Archaeutatus. Convex main figure, with a sharp and elevated central keel. In those osteoderms with large foramina on their surface, the main figure and keel rise above the level of the peripheral figures. Peripheral figures very convex to globose unlike $U$. buccatus, U. laxus, U. argos, and ?U. deustus.

Description. Fixed and movable osteoderms of ?Utaetus magnum sp. nov. have a slightly rough external surface (Figure 2A-G, I-M; Table 2), as in certain Euphractinae, and Astegotheriini, except for Astegotherium dichotomus, in which it is completely smooth (Vizcaíno, 1994). The lateral contact areas between osteoderms are straight, with denticular projections in their entire surface (Figure $2 \mathrm{H}$ ), similar to the condition observed in the paleogene Euphactinae Archaeutatus, and in the Cingulata incertae sedis Punatherium catamarcensis. In Utaetus the lateral faces are straight but, according to Ameghino (1902), the denticular projections are scarce or absent. By contrast, in Astegotheriini these surfaces are concave and smooth, and in Parutaetus punaensis they are concave with small and dispersed denticular projections (Ciancio et al., 2016). In ?U. magnum sp. nov. the piliferous system is underdeveloped. One or two conspicuous foramina can be observed in the posterior third of one or both lateral margins, as well as one or two small foramina can be observed in the posterior margin. Similar condition is present in "Utaetini", Astegotheriini, Archaeutatus, and Parutaetus (Simpson, 1948; Carlini et al., 2009, 2010; Ciancio et al., 2016). By contrast, the foramina are large and located in the posterior and lateral margins in P. catamarcensis. In most Euphractinae (Eutatini in particular) the piliferous system is well developed.

Ciancio et al. (2016) mentioned that rectangular and pentagonal fixed osteoderms are recognized in Parutaetus punaensis, and that the former would correspond to the lateral portion of the carapace, while the pentagonal ones would correspond to the middle region. In ?U. magnum sp. nov. the same variation in the shape of the osteoderms is observed.

The main figure of the rectangular osteoderms (Figure $2 \mathrm{~A}-\mathrm{D})$ is lageniform, very convex, and it has a sharpened central keel that extends nearly to the posterior margin of the osteoderm but not reaching it. These figures have a long, wide neck, reaching approximately one third of the osteoderms total length. Utaetus buccatus, U. argos, and ?U. deustus have a lageniform and convex main figure without keel. U. laxus has a flat main figure without keel. On the other hand, ?U. deustus has a convex main figure, with a low and not sharpened keel. The lageniform figure is also present in Astegoteriini and some euphractins like Orthutaetus, and Anteutatus. In "Utaetini”, Astegotheriini, and some Eocene Euphractinae, the neck is comparatively shorter (Ameghino, 1902; Carlini et al., 2010; Ciancio et al., 2013).

The new species has four peripheral polygonal figures, two anterior and two lateral, all convex or globose and similarly sized. In Utaetus buccatus, U. laxus, and Astegotheriini there are three to four flat or slightly convex and similarly sized anterolateral figures. Archaeutatus malaspinensis has two peripheral polygonal anterior figures that are well developed, and two smaller triangular lateral figures. In osteoderms of Punatherium catamarcensis there are three peripheral anterior figures and two slightly convex lateral figures.

In ?U. magnum sp. nov. the main figure is delimited by a wide, concave, and deep groove. Some of these osteoderms have a well-developed circular foramen at the intersection of the central groove with the radial groove, which delimits the anterior figures. In Utaetus buccatus and U. laxus the groove that delimits the main figure is narrow and has two to five circular foramina in the anterior region. In Astegotheriini, in general, the groove is narrow, shallow, and has two to 20 foramina of various sizes. A particular case is Pseudostegotherium in which the foramina of the anterior region are very well developed. In $A$. malaspinensis the groove that delimits the main figure is wide, concave and has two to four circular foramina. In Punatherium catamarcensis there are three circular foramina delimiting the anterior region of the main figure.

The fixed pentagonal osteoderms (Figures $2 \mathrm{E}-\mathrm{G}$ ) have very convex to globose figures. The main figure has a high, sharp keel that elevates above the level of the peripheral figures. In Utaetus buccatus and U. laxus the figures are not as convex, and the main figure does not rise above the level of the peripheral figures. There are two to three peripheral 
A

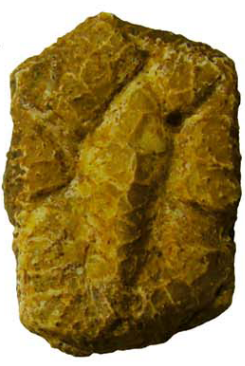

E

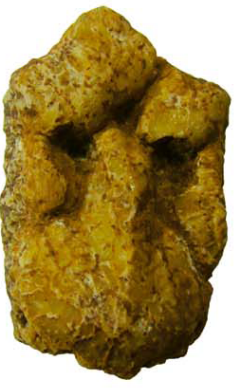

B

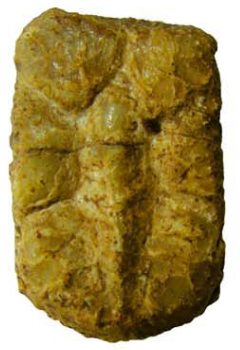

$\mathrm{F}$

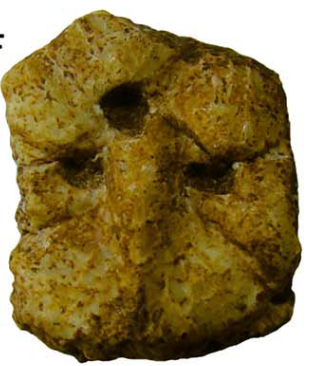

C

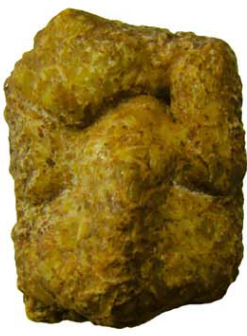

G

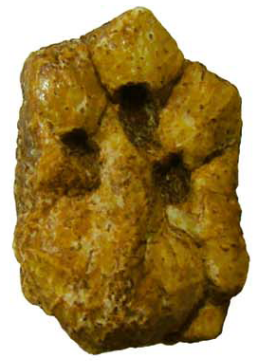

D

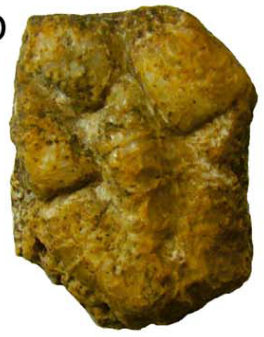

$\mathrm{H}$

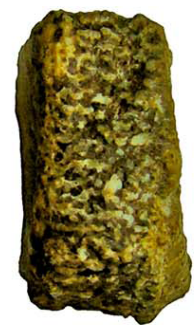

I

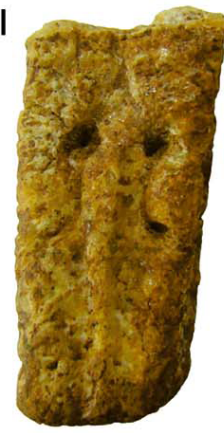

$\mathrm{L}$

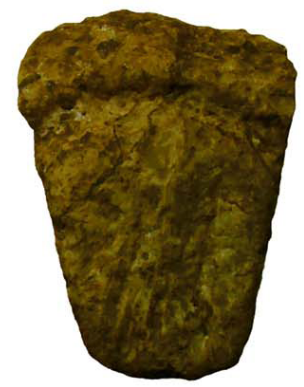

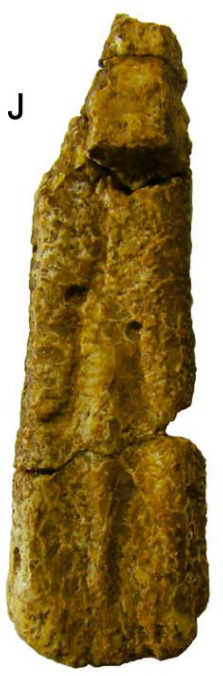

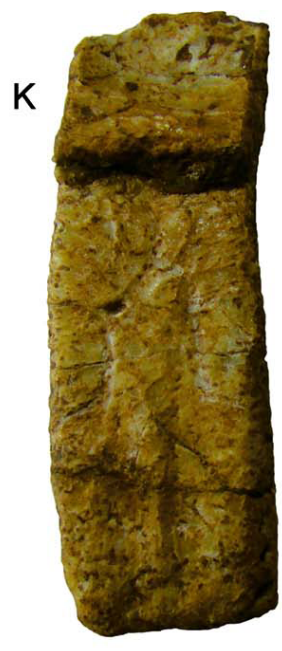

M

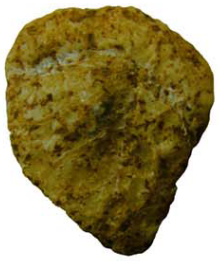

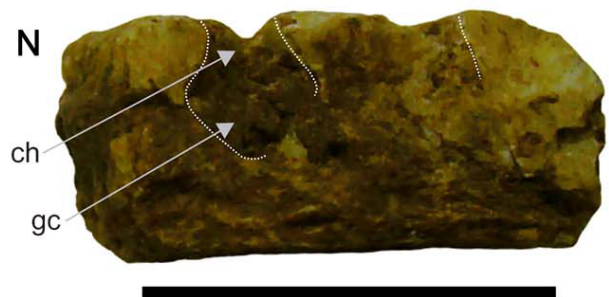

Figure 2. Osteoderms of ?Utaetus magnum sp. nov., IBIGEO-P 109. Quadrangular fixed osteoderms (A-D), pentagonal fixed osteoderms (E-G), lateral contact area in fixed osteoderm $(\mathbf{H})$, movable osteoderms $(\mathbf{I}-\mathbf{K})$, caudal sheath osteoderms $(\mathbf{L}, \mathbf{M})$, osteoderms $\mathbf{A}-\mathbf{M}$ are at the same scale. Cross section of osteoderms showing the foramen connected with glandular subspherical cavities, marked by the dotted line (N). Abbreviations: ch, channel; gc, glandular cavity. Scale bars $=10 \mathrm{~mm}$.

anterior figures and two lateral figures. The grooves that delimit the figures are deep and narrow. In the anterior region, the main figure has three large subcircular foramina. These large foramina are also found in U. buccatus (four or five), ?U. deustus (three or four), and U. laxus (two) (Ameghino, 1902; Ciancio \& Carlini, 2008; Carlini et al., 2010). In ?U. magnum sp. nov., the large foramina are connected with glandular subspherical cavities, that are well developed, through a short and very wide channel, as is observed in an osteoderm transversely cut (Figure 2N). A similar morphology has been described in the Stegosimpsonia and in the U. buccatus, which show hypertrophied glands (Ciancio et al., 2019).

The movable osteoderms (Figures 2I-K) have a lageniform convex main figure, with a blunt central keel that does not 
reach the posterior margin and is less prominent than in fixed osteoderms. ?Utaetus deustus also has a low central keel, while $U$. buccatus and $U$. laxus do not have this structure. The osteoderms have a long, wide neck that does not reach the anterior margin of its exposed region. Only a pair of peripheral figures limit the neck, each extending in the anterior and lateral region, which are slightly convex and extend up to half the length of the exposed region. A similar condition is observed in U. laxus, while in U. buccatus the main figure is open in the anterior margin of the exposed region and presents only one pair of lateral peripheral figures (Ciancio $\&$ Carlini, 2008). Movable osteoderms are unknown for $U$. argos. Parastegosimpsonia peruana also has a long neck, but it is surrounded by two pairs of peripheral figures, with an anterior pair and a lateral pair (Ciancio et al., 2013). In the other Astegotheriini, the main figure can be lageniform or triangular, flat or slightly convex, and in certain cases it has a short, blunt central keel. The neck extends up to the anterior margin of the exposed region; it is open and is limited by two lateral figures. In ?U. magnum sp. nov. the groove that delimits the main figure is deep and, around the neck, one to three circular foramina of smaller size than those of the fixed osteoderms occur. The transition zone is concave, short, and smooth. In U. buccatus, and U. laxus the transition zone is well developed and somewhat rough. In Astegotheriini, in general, the groove is narrow, shallow, and has circular foramina that vary in size and number (from one to eight). The transition zone is more developed; it is concave and can be smooth or rough.

The subtriangular osteoderms (Figures 2L, M) have a wide and rounded anterior edge, with a short articular region, as in Utaetus buccatus (MPEF PV 5426) from the middle Eocene of Patagonia, Argentina (Carlini et al., 2010). The transition zone is concave and deep. The exposed surface is rough, and the main figure is elongated, with an elevated keel, which does not reach the posterior margin of the osteoderm. There are no well-defined peripheral figures. The ventral surface is very concave in the transversal axis. These osteoderms are here regarded as part of the caudal sheath.

Size comparisons. The Euphractinae Utaetus buccatus, $U$. laxus, Parutaetus, Orthutaetus, Anteutatus, and the Cingulata incertae sedis Yuruatherium tropicalis, are medium-sized, similar to Chaetophractus villosus (movable osteoderms between 14-26 mm length, 5-11 mm width, 2.5-4.5 mm thick) (Ciancio \& Carlini, 2008; Carlini et al., 2010). The Astegotheriini (e.g. Riostegotherium, Prostegotherium, Parastegosimpsonia, Stegosimpsonia) are small to mediumsized, similar to the extant Dasypus hibridus or D. novemcinctus (movable osteoderms between 10-16 mm length, 5-8 mm width, 2-4 mm thick) (Oliveira \& Bergqvist, 1998; Tejedor et al., 2009). The only Stegotheriini from the Eocene is smaller than the above-mentioned taxa (Ciancio et al., 2013). Among the Eocene cingulate recorded in NWA, Astegotheriini, Euphractinae, and Punatherium catamarcensis, have similar sizes to those recorded for other latitudes. A particular case is ?U. deustus, which is larger than the other Utaetus species from Patagonia (movable osteoderms between 30-40 mm length, $15 \mathrm{~mm}$ width; Ameghino, 1902). On the other hand,
Lumbreratherium oblitum and Pucatherium parvum (known by more complete specimens) are medium-sized forms, similar to $D$. novemcinctus but with proportionally very small osteoderms (movable osteoderm between 4.82-9.60 mm length, and 4.07-5.58 mm width) (Herrera et al., 2012, 2016, 2019; Ciancio et al., 2016).

\section{DISCUSSION}

The new species presents similar morphological characters to Utaetus Ameghino (1902), such as the lageniform main figure, the presence in some osteoderms of large foramina on the external surface, and areas of lateral contact with denticular projections. The genus Utaetus comprises four species of which $U$. buccatus, U. laxus, and U. argos are of medium size, and only ?U. deustus is a large form (around two times larger than the others). The osteoderms of ?U. magnum sp. nov. are larger compared to ?U. deustus and other Eocene cingulates. Unlike all Utaetus species mentioned above, ?U. magnum sp. nov. has the main figure convex, the peripheral figures convex or globose, and the central keel sharp and raised.

During the Eocene, the succession of changes in the composition of cingulate faunas was different between high-latitude (Patagonia) and intermediate-latitude (NWA) deposits. The oldest records in Patagonia correspond to the early Eocene. In this period, the armadillos with the greatest diversity and abundance are Astegotheriini (Tejedor et al., 2009; Ciancio, 2016). In the middle Eocene, this group diversity decreased, simultaneously with the appearance of the first record of Euphractinae (Utaetus). Towards the late Eocene, the diversity of Euphractinae surpassed that of Astegotheriini and Stegotheriini.

In NWA, the sediments bearing Cingulata correspond to the span between the early to late Eocene (Powell et al., 2011; Ciancio et al., 2016; Herrera et al., 2012, 2016, 2019; Babot et al., 2017; Fernicola et al., 2021). In the early Eocene only two armadillos of uncertain affinities, unique to the NWA (Pucatherium parvum and Noatherium emilioi), are recorded. During the middle Eocene, the new species described here (?U. magnum sp. nov.) represents the oldest record of Euphractinae for this region. P. parvum and Lumbreratherium oblitum, exclusive forms of the NWA, are also recorded. In the late Eocene the most diverse group is Astegotheriini, while Euphractinae are represented by Parutaetus punaensis. Other taxa of uncertain affinities, such as Pucatherium parvum, and Punatherium catamarcensis, are recorded. To the present, some cingulate taxa that are frequently found in Patagonia, such as Stegotheriini, and Eutatini (Euphractinae), have not been yet recorded in NWA (Ciancio, 2016).

According to Fernicola et al. (2021), in the early Eocene deposits of the NWA there are three possible morphotypes of cingulate carapace. The first of them corresponds to a carapace formed entirely by transverse movable bands (Pucatherium parvum and Lumbreratherium oblitum); the second to a carapace with a scapular and pelvic shield separated by transverse movable bands (possibly Noatherium emilioi), and the third model with the entire anterior region formed by 
movable bands and a short pelvic shield (possibly N. emilioi). In the middle Eocene (Upper Lumbrera Formation), the $P$. parvum record show the presence of a carapace formed by movable bands; on the other hand ?U. magnum sp. nov. could present a carapace formed by movable bands, scapular shield, and pelvic shield or a carapace with movable bands and pelvic shield. Until now, no sufficiently complete specimen has been recovered to confirm the coexistence of these latter models throughout the Eocene. In relation to the articulation between contiguous osteoderms, ?U. magnum sp. nov. presents lateral contact areas straight with denticular projections in their entire surface, which allows us to infer a firm union between these osteoderms and little lateral mobility. On the other hand, $P$. parvum would present an exoskeleton with a high degree of lateral mobility between osteoderms (Herrera et al., 2019).

The identification of this new species assigned to ?Utaetus (?U. magnum sp. nov.) represents the oldest record of Euphractinae in NWA. In Patagonia and southern Brazil, the oldest records of Utaetus also come from the middle Eocene (Barrancan SALMA). Sedor et al. (2017) recognize, in addition to Utaetus, the cingulates Proeocoleophorus, Machlydotherium, Astegotheriini indet., Euphractinae indet., Meteutatus, and Parutaetus and points out that the fauna from Guabirotuba Formation (Southern Brazil), shares taxa with those of Patagonia (high-latitudes) and NWA (intermediate-latitudes). However, with the latter it only shares the genus Parutaetus, since Punatherium, Pucatherium, Lumbreratherium, and Noatherium represent an exclusive set of endemic cingulates for NWA. The recognition of this new species, an exclusive cingulate from the Upper Lumbrera Formation, strengthens the endemic character of the Paleogene faunas of NWA. This region was interpreted as an important Eocene diversification center for a variety of endemic South American lineages (Reguero et al., 2008). In the case of Cingulata, Pucatherium parvum and Lumbreratherium oblitum, a basal monophyletic clade, constitute a clearly different lineage from all other armadillos, and are peculiarly characterized by size, general morphology, and articulation of osteoderms (Herrera et al., 2016). Besides xenarthrans, NWA served as an area of origin of intertropical clades of notoungulates, which have striking taxonomical differences compared to those originating in the Paleogene of southern SA, and Patagonia in particular (Reguero et al., 2008; García-López \& Powell, 2011; Powell et al., 2011). Therefore, this pattern of archaic endemism evidenced in cingulates is supported by notoungulates and also observed among crocodiles, with the presence of unique forms of sebecids that contribute to the singular fauna found in this region (Bravo, 2019).

\section{ACKNOWLEDGMENTS}

We thank L. Mercado and P. Camaño, from the Museum of Anthropology of Salta, Argentina, for granting exploration permits, to Estancia Pampa Grande for permission to develop fieldwork on their property, to the curators M. Reguero (MLP), P. Ortiz (PVL), and former curator A. Kramarz (MACN) for making available the collections under their care, to
S.A. Nanni by revisions of the texts in English. Financial support was provided by Consejo de Investigaciones de la Universidad Nacional de Tucumán (PIUNT 2018 G626 to P. Ortiz), and Consejo Nacional de Investigaciones Científicas y Tecnológicas (PICT-2016-3682 to N. Gianinni, PICT-20161274 to C. del Papa, PICT-2015-1522 to S. Bertelli). We would like to thank the reviewers for their insightful comments on the paper, as these comments led us to an improvement of the work. The authors also thank Facultad de Ciencias Naturales e Instituto Miguel Lillo (Universidad Nacional de Tucumán) and Fundación Miguel Lillo for research and facilities support.

\section{REFERENCES}

Ameghino, F. 1902. Notices préliminaires sur des mammiferes nouveaux des terrains crétacés de Patagonie. Boletín de la Academia Nacional de Ciencias en Córdoba, 17:5-70.

Babot, M.J.; García-López, D.A.; Deraco, V.; Herrera, C.M. \& del Papa, C. 2017. Mamíferos paleógenos del subtrópico de Argentina: síntesis de estudios estratigráficos, cronológicos y taxonómicos. In: C.M. Muruaga \& P. Gross (eds.) Ciencias de la Tierra y Recursos Naturales del NOA, Relatorio del XX Congreso Geológico Argentino, p. 730-753.

Babot, M.J.; García-López, D.A. \& Gaudin, T.J. 2012. The most ancient xenarthran petrosal: morphology and evolutionary significance. Journal of Vertebrate Paleontology, 32:1186-1197. doi:10.1080/02724634.2012.686466

Bergqvist, L.P.; Abrantes, É.A.L. \& Ávilla, L.S. 2004. The Xenarthra (Mammalia) of São José de Itaboraí Basin (upper Paleocene, Itaboraian), Rio de Janeiro, Brazil. Geodiversitas, 26:323-337.

Bravo, G.G. 2019. Estudio morfológico y sistemático de un registro de Sebecidae (Mesoeucrocodylia, Sebecosuchia) para la Formación Mealla (Paleógeno), provincia de Jujuy, Argentina. Facultad de Ciencias Naturales e Instituto Miguel Lillo, Universidad Nacional de Tucumán, B. S. Thesis, 84 p.

Carlini, A.A.; Ciancio, M.R.; Flynn, J.J.; Scillato-Yané, G.J. \& Wyss, A.R. 2009. The phylogenetic and biostratigraphic significance of new armadillos (Mammalia, Xenarthra, Dasypodidae, Euphractinae) from the Tinguirirican (Early Oligocene) of Chile. Journal Systematic Palaeontology, 7:489-503. doi:10.1017/ S1477201908002708.

Carlini, A.A.; Ciancio, M.R. \& Scillato-Yané, G.J. 2010. Middle Eocene-Early Miocene Dasypodidae (Xenarthra) of southern South America: faunal succession at Gran Barranca-biostratigraphy and paleoecology. In: R.H. Madden; A.A. Carlini; M.G. Vucetich \& R.F. Kay (eds.) The Paleontology of Gran Barranca: Evolution and Environmental Change through the Middle Cenozoic of Patagonia, Cambridge University Press, p. 106-129.

Castro, M.C. 2015. Sistemática y evolución de los armadillos Dasypodini (Xenarthra, Cingulata, Dasypodidae). Revista del Museo de La Plata, 15:1-50.

Ciancio, M.R. 2016. Los armadillos (Dasypodidae, Xenarthra) del Cenozoico temprano-medio de Argentina: aspectos evolutivos, bioestratigráficos y biogeográficos. Contribución del Museo Argentino de Ciencias Naturales, 6:231-247.

Ciancio, M.R. \& Carlini, A.A. 2008. Identificación de ejemplares tipo de Dasypodidae (Mammalia, Xenarthra) del Paleógeno de Argentina. Revista del Museo Argentino de Ciencias Naturales, 10:221-237.

Ciancio, M.R.; Carlini, A.A.; Campbell, K.E. \& Scillato-Yané, G.J. 2013. New Palaeogene cingulates (Mammalia, Xenarthra) 
from Santa Rosa, Perú and their importance in the context of South American faunas. Journal Systematic Palaeontology, 11:727-741, doi:10.1080/14772019.2012.704949.

Ciancio, M.R.; Herrera, C.M.; Aramayo, A.; Payrola, P. \& Babot, M.J. 2016. Diversity of cingulates (Mammalia, Xenarthra) in the middlelate Eocene of Northwestern Argentina. Acta Paleontologica Polonica, 61:575-590. doi:10.4202/app.00208.2015

Ciancio M.R.; Krmpotic, C.M.; Scarano, A.C. \& Epele, M.B. 2019. Internal morphology of osteoderms of extinct armadillos and its relationship with environmental conditions. Journal Mammalian Evolution, 26:71-83. doi:10.1007/s10914-017-9404-y

Cione A.L.; Gasparini, G.M.; Soibelzon, E.; Soibelzon, L.H. \& Tonni, E.P. 2015. The Great American Biotic Interchange. A South American Perspective. New York, London, Springer, 106 p.

del Papa, C.E. 2006. Estratigrafía y paleoambientes de la Formación Lumbrera, Grupo Salta, Noroeste Argentino. Revista de la Asociación Geologica Argentina, 61:313-327.

del Papa, C.; Aramayo, A.; Payrola Bosio, P.; Hongn, F.; Montero López, C.; Do Campo, M.; Deraco, V.; Herrera, C.; Petrinovic, I. \& Lapiana. A. 2017. La cuenca de antepaís Eocena-Oligocena en el NOA: primeros indicios de deformación intra-cuenca. In: C.M. Muruaga \& P. Grosse (eds.) Ciencias de la tierra y recursos naturales del NOA, Relatorio del XX Congreso Geológico Argentino, Asociación Geológica Argentina, p. 237-253.

del Papa, C.E.; Kirschbaum, A.; Powell, J.E.; Brod, A.; Hongn, F. \& Pimentel, M. 2010. Sedimentological, geochemical and paleontological insights applied to continental omission surfaces: a new approach for reconstructing an Eocene foreland basin in NW Argentina. Journal of South American Earth Sciences, 29:327-345. doi:10.1016/j.jsames.2009.06.004

Fernicola, J.C.; Zimicz, A.N.; Chornogubsky, L.; Cruz, L.E.; Bond, M.; Arnal, M.; Cárdenas, M. \& Fernández, M. 2021. New assemblage of cingulates from the Quebrada de Los Colorados Formation (middle Eocene) at Los Cardones National Park (Salta Province, Argentina) and the Casamayoran SALMA problem at Northwestern Argentina. Journal of South American Earth Sciences, 111:103476. doi:10.1016/j.jsames.2021.103476

García-López, D.A. \& Powell, J.E. 2011. Griphotherion peiranoi, gen. et sp. nov., a new Eocene Notoungulata (Mammalia, Meridiungulata) from northwestern Argentina. Journal of Vertebrate Paleontology, 31:1117-1130. doi:10.1080/027246 34.2011.599464

Gelfo J.N.; Goin, F.J.; Woodburne, M.O. \& Muizon, C. 2009. Biochronological relationships of the earliest South American Paleogene mammalian faunas. Palaeontology, 52:251-269. doi:10.1111/j.1475-4983.2008.00835.x

Herrera C.M.; del Papa C.E. \& Hongn, F. 2010. Nuevos registros de dasipódidos eocenos para la Formación Quebrada de Los Colorados en el tramo central del Valle Calchaquí (Salta, Argentina). In: CONGRESO ARGENTINO DE PALEONTOLOGÍAY BIOESTRATIGRAFÍA, X, CONGRESO LATINOAMERICANO DE PALEONTOLOGÍA, 7, 2010. Libro de resúmenes, Buenos Aires, p. 63.

Herrera, C.M.R.; Esteban, G.I.; Ciancio, M.C. \& del Papa, C. 2019. New specimen of Pucatherium parvum (Xenarthra, Dasypodidae), a singular dasypodid of the Paleogene (Eocene) of Northwest Argentina. Importance in the early evolution of armadillos. Journal of Vertebrate Paleontology, 39:4. doi:10.1 080/02724634.2019.1670669.

Herrera, C.M. \& Powell, J.E. 2009. Primer registro de astegoterinos (Dasypodidae, Cingulata) de la Formación Quebrada de los Colorados (Grupo Payogastilla) en la Provincia de Salta. Ameghiniana, 46:18.
Herrera, C.M.; Powell, J.E. \& del Papa, C. 2012. Un nuevo Dasypodidae (Mammalia, Xenarthra) de la Formación Casa Grande (eoceno) de la provincia de Jujuy, Argentina. Ameghiniana, 49:267-271. doi:10.5710/AMGH.v49i2(502)

Herrera, C.M.R.; Powell, J.E.; Esteban, G.I. \& del Papa, C. 2016. A new Eocene dasypodid with caniniforms (Mammalia, Xenarthra, Cingulata) from Northwest Argentina. Journal Mammal Evolution, 24:275-288. doi:10.1007/s10914-016-9345-x

Lapiana, A.T.; del Papa, C. \& Gaiero, D. 2016. Los depósitos limolíticos eocenos de la Formación Lumbrera superior (Salta, Argentina): discusión sobre el posible origen eólico. Latin American Journal of Sedimentology and Basin Analysis, 3:743-758.

Oliveira, E.V. \& Bergqvist, L. 1998. A new Paleocene armadillo (Mammalia, Dasypodoidea) from the Itaboraí basin, Brazil. Asociación Paleontologica Argentina, 5:35-40.

Patterson, B. \& Pascual, R. 1968. Evolution of mammals on southern continents. Quaterly Review of Biology, 43:409-451.

Powell, J.E.; Babot, M.J.; García-López, D.A.; Deraco, M.V. \& Herrera, C. 2011. Eocene vertebrates of northwestern Argentina: annotated list. In: J.A. Salfity \& R.A. Marquillas (eds.) Cenozoic Geology of the Central Andes of Argentina, SCS Publisher, p. 349-370.

Reguero, M.A.; Croft, D.A.; Lopez, G.M. \& Alonso, R.N. 2008. Eocene archaeohyracids (Mammalia: Notoungulata: Hegetotheria) from the Puna, Northwest Argentina. Journal of South American Earth Sciences, 26:225-233. doi:10.1016/j. jsames.2008.05.004

Sedor, F.; Oliveira, E.V.; Silva, D.D.; Fernandes, L.A.; Cunha, R.F.; Ribeiro, A.M. \& Dias, E.V. 2017. A new South American Paleogene Land Mammal Fauna, Guabirotuba Formation (Southern Brazil). Journal of Mammalian Evolution, 24:39-55. doi:10.1007/s10914-016-9364-7

Simpson, G.G. 1948. The beginning of the age of mammals in South America. Part I Introduction. Edentata, Condrylarthra, Liptoterna, and Notioprotogonia. Bulletin of the American Museum of Natural History, 91:1-232.

Soibelzon, E.; Avilla, L.S. \& Castro, M. 2015. The cingulates (Mammalia: Xenarthra) from the late Quaternary of northern Brazil: fossil records, paleoclimates and displacements in America. Quaternary International, 377:118-125. doi:10.1016/j. quaint.2015.02.052

Tejedor, M.F.; Goin, F.J.; Gelfo, J.N.; López, G.M.; Bond, M.; Carlini, A.A; Scillato-Yané, G.J.; Woodburne, M.O.; Chornogubsky, L.; Aragón, E.; Reguero, M.A.; Czaplewski, N.J.; Vincon, S.; Martin, G.M. \& Ciancio, M. 2009. New early Eocene mammalian fauna from Western Patagonia, Argentina. American Museum Novitates, 3638:1-43.

Vizcaíno, S.F. 1994. Sistemática y Anatomía de los Astegotheriini Ameghino, 1906 (Nuevo Rango) (Xenarthra, Dasypodidae, Dasypodinae). Ameghiniana, 31:3-13.

Woodburne, M.O.; Goin, F.J.; Raigemborn, M.S.; Heizler, M.; Gelfo, J.N. \& Oliveira, E.V. 2014. Revised timing of the South American early Paleogene land mammal ages. Journal of South American Earth Sciences, 54:109-119. doi:10.1016/j. jsames.2014.05.003Get

Received in 26 February, 2021; accepted in 18 June, 2021. 